ROELAND PAARDEKOOPER

EXARC, The Netherlands

r.p.paardekooper@exarc.net

MILICA TAPAVIČKI-ILIĆ

Institute of Archaeology, Belgrade, Serbia

JELENA ANĐELKOVIĆ GRAŠAR

Institute of Archaeology, Belgrade, Serbia
001.92:902(497.11)"2014"

904"652"(497.11)

COBISS.SR-ID 219299596

Original research article

Received: July 27th 2015

Accepted: November 15th 2015

\title{
VIMINACIUM AND THE OPENARCH PROJECT
}

\begin{abstract}
With the idea of popularising Archaeological Open-Air Museums, archaeology as well as science, the OpenArch project was created within the EU Culture Programme. This five year project connects Archaeological Open-Air Museums from eight European countries, among which Viminacium is the only Archaeological Park. Many activities have been held in Viminacium since the beginning of the project, including two international symposia, experiments and staff exchanges. All these have brought great benefits to the experience of the management of the Viminacium Archaeological Park and to its promotion among national and international audiences, as well as to the OpenArch partners, better informing them about the challenges of popularising archaeology in the Balkans.
\end{abstract}

\section{KEYWORDS: OPENARCH, VIMINACIUM, ARCHAEOLOGICAL OPEN-AIR MUSEUM, ARCHAEOLOGICAL PARK, EXPERIMENTAL ARCHAEOLOGY, POPULARISATION.}

\section{OPENARCH PROJECT}

OpenArch is a project funded by the EU as part of its Culture Programme and is based on the EXARC experience of international cooperation. EXARC is the international ICOM Affiliated Organisation for archaeological open-air museums, experimental archaeology, interpretation of scientific methodology and ancient technology, and has 250 members in 30 countries. The main idea of the project is to present both the tangible and intangible past to the public, through archaeological remains or reconstructions or the story of the people that lived in the past. The work of OpenArch is divided into Work Packages and one or two partners coordinate them. The leading partner on the project is Calafell (CAT), ${ }^{1}$ while the other partners are Foteviken (SE), ${ }^{2}$ Kierikki (FI), ${ }^{3}$ Archeon (NL), ${ }^{4}$ Hunebedcentrum (NL), ${ }^{5}$ AÖZA (DE), ${ }^{6}$ Terramara di Montale (IT), ${ }^{7}$ The Nation-

1 The article results from the project: IRS-Viminacium, Roman city and military camp - research of material and non material culture of inhabitants by using the modern technologies of remote detection, geophysics, GIS, digitalisation and $3 D$ visualisation (no 47018), funded by The Ministry of Education, Science and Technological Development of the Republic of Serbia, and the OpenArch project.

Read more at www.ciutadellaiberica.com.

2 Read more at www.foteviken.se.

3 Read more at www.kierikki.fi.

4 Read more at www.archeon.nl.

5 Read more at www.hunebedcentrum.nl.

6 Read more at www.steinzeitpark-dithmarschen.de.

7 Read more at www.parcomontale.it. 
al Museum of Wales (WLS), ${ }^{8}$ The University of Exeter (EN), ${ }^{9}$ The Institute of Archaeology, Project Viminacium (RS) ${ }^{10}$ and EXARC (NL). ${ }^{11}$ The Work Packages are Project Management, Improvement of Museum Management, Dialogue with Visitors, Dialogue with Skills, Dialogue with Science, Dialogue with Museum Organisations and, finally, Communication \& Dissemination. The coordinators of the Work Package - Dialogue with Visitors - are Archeon (NL) and The Institute of Archaeology-Viminacium (RS). This Work Package focuses on the presentation of archaeology to the public. The partners have great expertise in presenting and working with the living history of sites and their history. The aim of this Work Package is to help children, young people and adults of all ages to discover their own local history, using the OpenArch method. A significant asset of archaeological open-air museums is that they do not attract a limited target group like more traditional museums do. ${ }^{12}$

\section{VIMINACIUM}

Viminacium is an ancient Roman site on the right bank of The Danube, in eastern Serbia. With the remains of a military camp, a city and a necropolis, in 2006 Viminacium became the first Archaeological Park in Serbia to open for visitors the whole year round. The history of the site dates back to the $1^{\text {st }}$ century AD, when two Roman legions, IV Flavia and VII Claudia, founded the military camp. Later, the civilian settlement was founded and it grew into a city which became the capital of the Roman province Moesia Superior, or Upper Moesia (Moesia Prima) in Late Antiqui-

8 Read more at www.museumwales. ac.uk/en/stfagans.

9 Read more at www.exeter.ac.uk/archaeology.

10 Read more at www.viminacium.org.rs.

11 Read more at www.exarc.net.

12 Read more in: Paardekooper 2012; More about this Work Package at http://openarch.eu/work-packages/dialogue-visitors ty. ${ }^{13}$ Viminacium was destroyed by Hunnic attacks in 441/443. Today, remains of the city and the military camp lay beneath fertile grain and corn fields in an area larger than 450 hectares. The first excavation at Viminacium started at the end of the $19^{\text {th }}$ century ${ }^{14}$ and, after a long pause, resumed in the 1970's. ${ }^{15}$ Today, protective field excavations of the city, the military camp and the cemeteries are carried out by a multidisciplinary team of The Institute of Archaeology. Objects discovered during these excavations are presented to the public in the Viminacium Archaeological Park. It is of great importance that, besides the protective construction which is made of laminated wood and a so called French tent, the permanent visits prevent the site from being robbed, as had happened in the past. ${ }^{16}$ The opening of the archaeological park took place in 2006, when all the necessary facilities were established, such as infrastructure, staff, security, etc. ${ }^{17}$ The initial tourist itinerary was defined as Porta praetoria, ${ }^{18}$ Thermae $^{19}$ and

13 More about Viminacium in: Спасић-Ђурић 2002; www.viminacium.org.rs

14 These excavations were conducted by Mihailo Valtrović, Serbian architect and art historian and Miloje Vasić, the founder of Serbian archaeology. Cf. Валтровић 1884a: 3-14; Валтровић 1884b: 121-142; Васић 1907: 67-98; Васић 1895: 1-61.

15 Excavation works were conducted by the Institue of Archaeology and the State Institute for the Protection of Cultural Monuments, mostly focused on Viminacium cemeteries. Cf. Зотовић 1986: 41-60; Зотовић 2000: 7-17; Зотовић and Јордовић 1990.

16 More about various threats and methods of protection in: Nikolić et al. 2013: 205-214.

17 More about the Viminacium Archaeological Park in: Maksin et al. 2011: 331-339; Anđelković Grašar et al. 2013: 9-14; Golubović and Korać 2013: 65-74; Golubović and Tapavički-Ilić 2012: 67-73; Tapavički-Ilić 2013: 315-326.

18 Porta Praetoria, the northern gate of the Viminacium castrum and the remains of its two entrances with stone pavements, the basements of two towers and the sewage system, were shown at the beginning of the Viminacium tour. $C f$. Golubović and Korać 2013: 68-69.

19 Termae - Roman baths are preserved in several levels from different periods between the $1^{\text {st }}$ and the $4^{\text {th }}$ century. There are visible remains of the hypocaust, floor heating, together with four pools for warm or hot water, and a fifth pool for cold water. Baths were luxuriously furnished with 


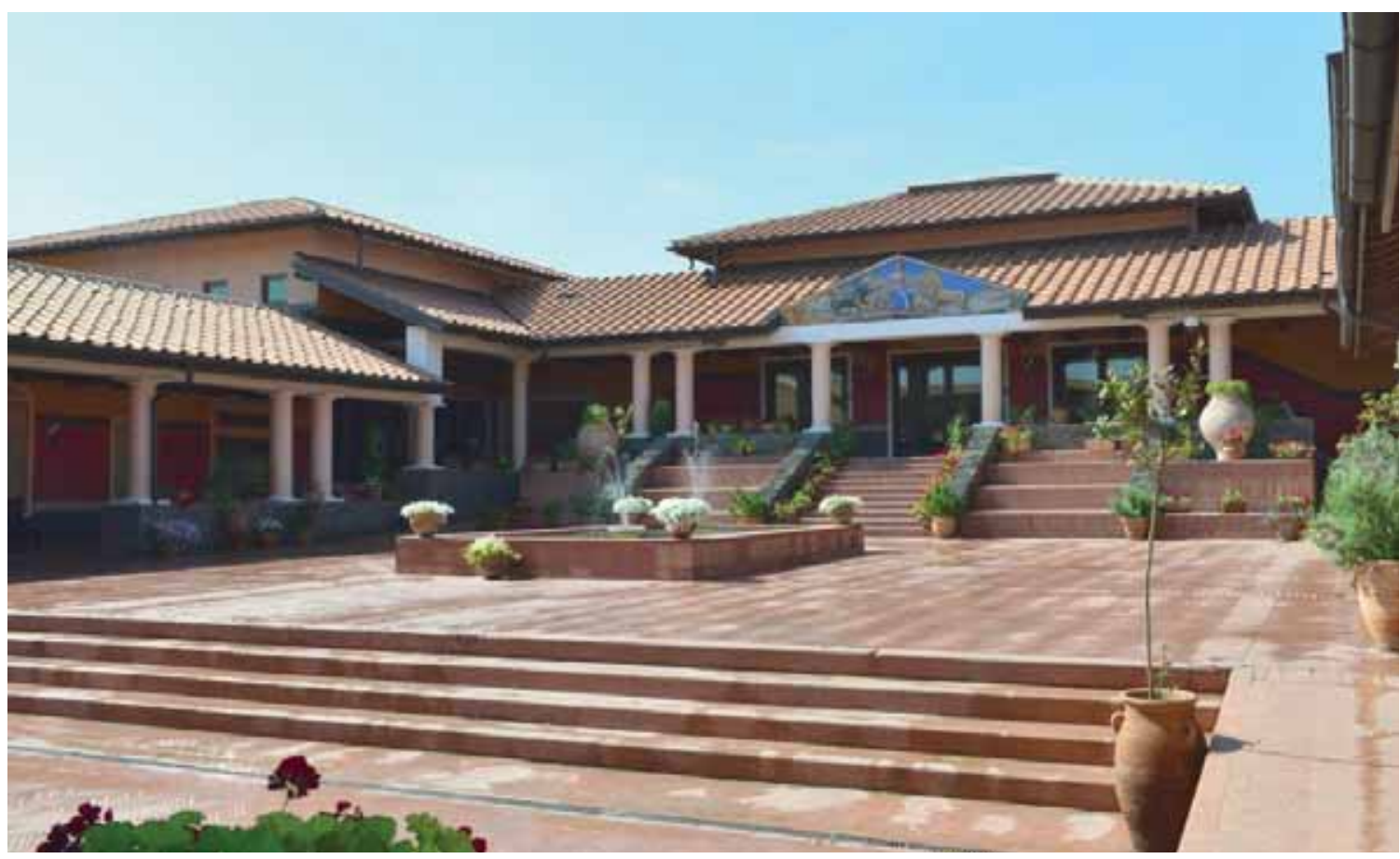

Fig. 1 Domus Scientiarium Viminacium, Scientific, Research and Visitors Center

Mausoleum ${ }^{20}$ with underground structures ${ }^{21}$ Since the beginning of the building project in 2008, the Domus Scientiarium has also become an important part of visits and events at Viminacium (Fig. 1). ${ }^{22}$ Today, the Viminacium Archaeological Park has been enlarged to include the site of the amphitheatre, which has been excavated since 2008, (Nikolić et al. 2014: 58-62; Nikolić and Bogdanović 2012: 42-45; Rogić and Bogdanović 2012, 4649; Nikolić and Bogdanović 2012: 58-61) while

mosaics and fresco decoration. $C f$. Миловановић 2004/5: 51-54; Rogić et al. 2007: 75-82.

20 The mausoleum is located at the Pirivoj necropolis and it is believed that this is the so-called tomb of the Roman emperor Hostilian, who is thought to have died at Viminacium. $C f$. Реџић 2008: 59-61; Jovanović 2006: 39; Korać et al. 2009: 98-99.

21 Within the Viminacium basement, "Tomb with Cupids" (G-160) is presented with its original frescoes in situ, while the frescoes of two other tombs - "Pagan tomb" (G2624) and "Christian tomb" (G-5517) are now kept at the National Museum in Požarevac and copies are have been installed in the tomb to resemble the original context. $C f$. Anđelković Grašar et al. 2013: 73-100; Korać 2007: 157168, 168-185, 186-188; Anđelković 2012: 1-6.

22 The Scientific, Research and Visitors Centre, called the Domus Scientiarium is today a completed complex in the design of a Roman villa. Cf. Nikolić 2012: 66-68. in June 2014, the Mammoth Park was opened, along with a playground for the younger visitors (Mrđić and Jovičić 2014: 54-57).

The Viminacium Archaeological Park is visited by between 50.000 and 75.000 visitors each year, with numerous children's excursions, senior groups and individual visitors, who are the most common visitors at weekends, as well as tourists from cruises (Anđelković Grašar and Tapavički-Ilić 2014: 191-204). Besides the importance of the archaeological remains, at the Viminacium Archaeological Park, special attention is dedicated to additional activities which are of great importance to the experience and emotions of its visitors. ${ }^{23}$ Among other things, Viminacium visitors noted that the most important part of the Viminacium tour were the interesting and informative explanations offered by the expert guides, which serve to improve and reinforce the impressions of the ancient ruins and archaeological remains (Anđelković Grašar and Tapavički-Ilić 2014: 191204). Owing to its extensive of experience man-

23 More about Archaeological park in theory and practice in: Nikolić et al. 2011: 259-268. 


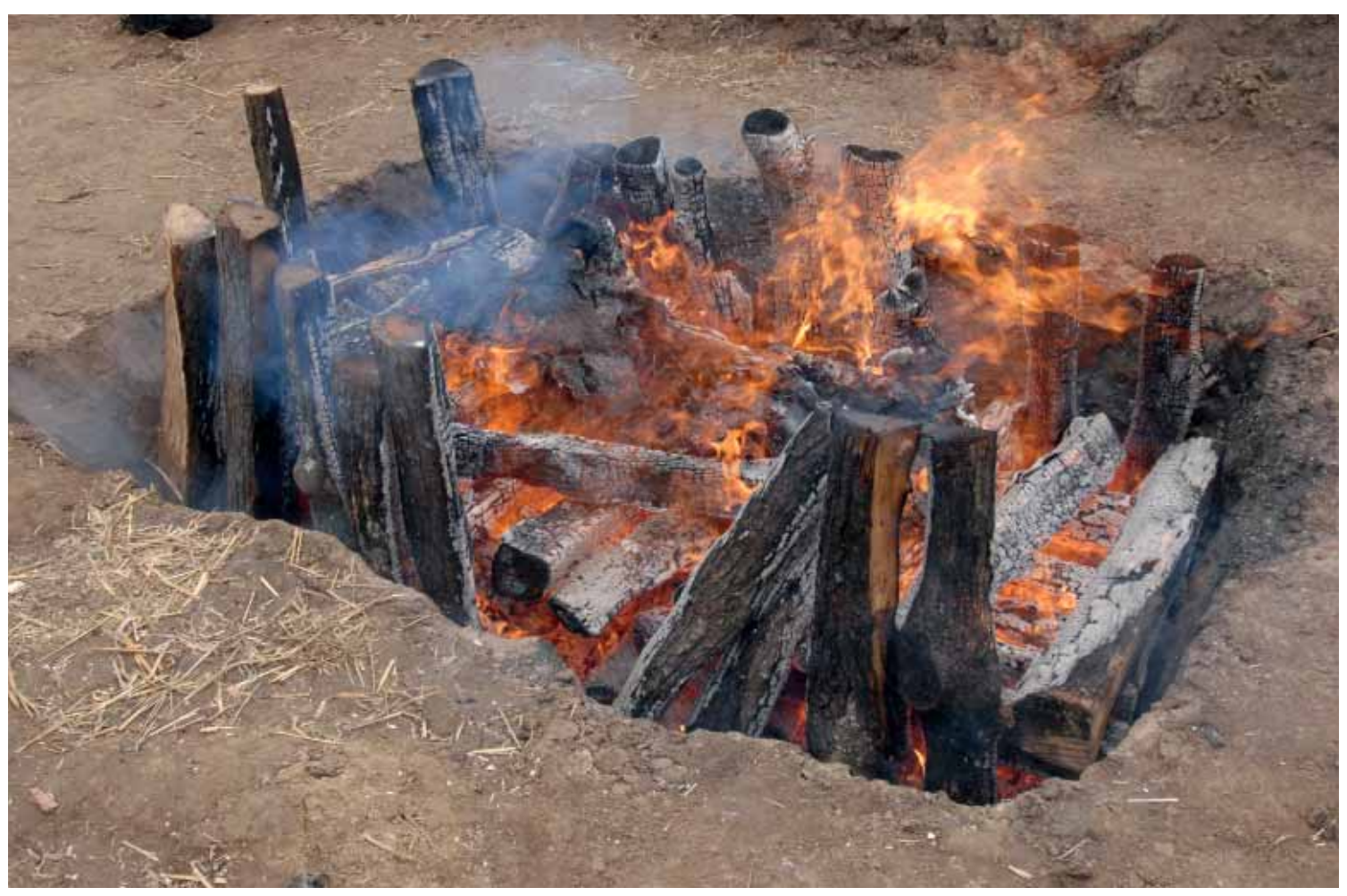

Fig. 2 Experimental Archaeology, Experiment of Roman cremation of the Mala Kopašnica - Sase type

aging the archaeological park, Viminacium has become one of the coordinators of the Dialogue with Visitors Work Package.

\section{PROJECT'S ACTIVITIES}

Among other activities within the OpenArch project there are meetings and workshops, focused on presentations, lectures and discussion groups regarding 'working together' and staff sessions of the archaeological open-air museums with the aim of exchanging insight into specific methods and of improving each other's skills and abilities. Staff exchanges are considered to be a tool for the exchange of best practices between staff of different museums, targeting of those day to day workers of the museum who are closest to the general public and schools. Experiments and experimental actions are required in order to understand how objects were made, how constructions might have appeared and, not the least, how people in the past behaved. ${ }^{24}$ Within the OpenArch project, two experiments were conducted at Viminacium on $19^{\text {th }}$ March, 2013. The first included a Roman cremation of the Mala Kopašnica - Sase type, typical for the area of the Middle Balkans from the $1^{\text {st }}$ to the $3^{\text {rd }}$ century AD (Fig. 2). The cremated remains (of a pig, for the purpose of this experiment) were later transferred to a grave pit. The results gained from this experiment, which was carried out under various conditions, formed the basis for further discussion on the differences between funerary rites. Some of the conclusions obtained from the experiment show that the remains of the deceased were not cremated within the burial pit, and that the amount of ash which was discovered during excavations does not match the amount that remains after a cremation in situ. The burial pit was most likely prepared in a separate ritual and after baking its walls, when everything was clear, the remains of the already cremated deceased were deposited

24 More about the project's activities in: Tapavički-Ilić and Anđelković Grašar 2013: 97-100. 




Fig. 3 Experimental Archaeology, Experiment of planting grapevine according to Roman customs and practices taken from ancient Roman authors

into it. Thus the funeral of the deceased was carried out in three phases, i.e. three separate rituals. ${ }^{25}$

The second experiment included planting ungrafted (not cross-bred) grapevines according to Roman customs and practices taken from ancient Roman authors (Fig. 3). The planting was made next to elm trees along the parking lot next to the building of the Domus Scientiarium, during the week of the waning moon and included some twenty young grapevines. For the purpose of the experimental planting, replicas of agricultural tools were made (Ilić et al. in print).

It is of great importance that two international symposia were held at Viminacium, both for the OpenArch partners and for the employees of museums and scientific institutions from the Balkans. The first international symposium, "Archaeological Heritage - its Role in Education, Presentation and the Popularisation of Science", took place at Viminacium between $5^{\text {th }}$ and $8^{\text {th }}$ October 2012 and host-

25 More about this experiment in: Tapavički-Ilić and Mrđić, in print. ed researchers from the EU, the Balkans, as well as from, amongst others, Russia, Japan and Africa. The second international symposium "The Impact of the Dialogue with Visitors on the Management of Archaeological Open-Air Museums" also took place at Viminacium, between $29^{\text {th }}$ September and $3^{\text {rd }}$ October 2014. On both occasions, books of abstracts and the conference proceedings were published by the Institute of Archaeology, Belgrade and the Centre for New Technologies, Viminacium.

On $5^{\text {th }}$ July 2014, the Danube Limes Day was organised at the Viminacium Archaeological Park, basically dedicated to children (Fig. 4). Reconstructions of ancient fighting techniques and Roman games were conducted by colleagues in the OpenArch project from Archeon (the Netherlands) and the Institute of Archaeology, Belgrade. At the end of the day, children and their parents, along with other audience members, enjoyed tasting food prepared according to Roman recipes and listened to a concert in the main atrium of the Domus Scientiarium. 


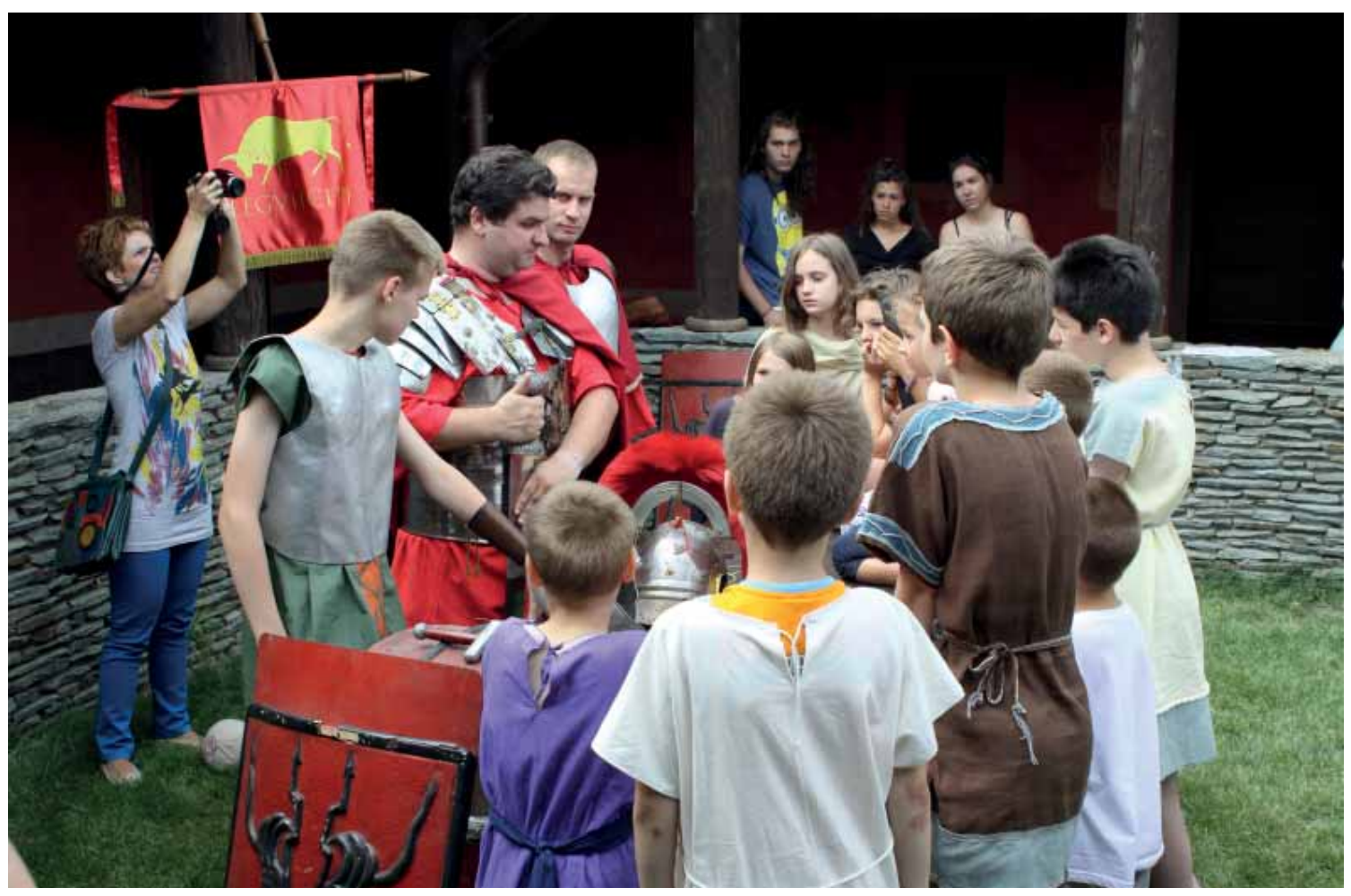

Fig. 4 Roman day at Viminacium, Danube Limes Day

\section{BIBLIOGRAPHY}

\section{Anđelković 2012}

Anđelković, J., Painted Tombs from Viminacium and Their Presentation to the Public, in: Chowaniec R. and Więckowski W. (eds.), Archaeological Heritage: Methods of Education and Popularisation, BAR International Series 2443, (2012), $1-6$.

\section{Anđelković Grašar et al. 2013}

Anđelković Grašar, J., Nikolić, E. and Rogić, D., "Tomb with Cupids" from Viminacium: a Contribution to Research of Construction, Iconography and Style, Starinar 63 2013, 73-100.

\section{Anđelković Grašar and Tapavički-Ilić 2014}

Anđelković Grašar, J., and Tapavički-Ilić, M., Senior visitors, junior enthusiasm: analysis of visitors' questionnaire, Archaeology and Science 9 (2013), 2014, 191-204.
Anđelković Grašar et al. 2013

Anđelković Grašar, J., Rogić, D. and Nikolić, E., Viminacium, Archaeological Park - Modern Code for Re-reading the Past of the Roman City and Legionary Camp, in: Studies on Disasters, Catastrophes and the Ends of the World in Sources, Acta Archaeologica Pultuskiensia, Vol. IV, (eds.) J. Popielska-Grzybowska, J. Iwaszczuk, Pultusk 2013, 9-14.

\section{Golubović and Korać 2013}

Golubović, S. and Korać, M., Bringing to life the Ancient City of Viminacium on the Danube, (ed.) Nigel Mills, in: Presenting the Romans: Interpreting the Frontiers of the Roman Empire World Heritage Site, Woodbridge, The Boydell Press, 2013, 65-74.

\section{Golubović and Tapavički-Ilić 2012}

Golubović, S. and Tapavički-Ilić, M., The Viminacium Archaeological Park and Scientific and Research Centre, in: Chowaniec R. and Więckowski W. (eds.), Archaeological Heritage: Meth- 
ods of Education and Popularisation, BAR International Series 2443, (2012): 67-73.

\section{Ilić et al. in print}

Ilić, O., Tapavički-Ilić, M. and Ćirić, Đ., Viminacijum: eksperimentalna arheologija u okviru projekta OpenArch, in: Arheologija u Srbiji, projekti Arheološkog instituta u 2013. godini, (ed.) D. Antonović, in print.

\section{Jovanović 2006}

Jovanović, A., Tlo Srbije: Zavičaj rimskih careva, Beograd 2006.

\section{Korać et al. 2006a}

Korać, M., Stojanović, V. and Mrđić, N., Primena georadara $\mathrm{u}$ istraživanjima rimskog akvedukta na Viminacijumu, (Application of Ground Penetrating Radar (GPR) During Excavations of Roman Aqueduct in Viminacium), Archaeology and Science I, (2006), 37-46.

\section{Korać et al. 2006b}

Korać, M., Pavlović, R., and Mrđić, N., Viminacijum-daljinska detekcija i GIS (Viminacium - Remote Sensing and GIS), Archaeology and Science I, (2006), 21-36.

\section{Korać 2007}

Korać, M., Slikarstvo Viminacijuma, Beograd 2007.

\section{Korać et al. 2009}

Korać, M., Golubović, S. and Mrđić, N., Itinerarivm Romanvm Serbiae, Belgrade 2009.

\section{Maksin et al. 2011}

Maksin, M., Pucar, M., Milijić, S. and Korać, M., Održivi razvoj turizma u Evropskoj Uniji I Srbiji. Beograd 2011.

\section{Mikić et al. 2006}

Mikić, M., Stojanović, V. and Mrđić, N., Primena gradiometra za potrebe zaštitnih arheoloških is- traživanja na Viminacijumu - lokalitet Rit, (Use of Gradiometer During Protective Archaeological Research at Viminacium - Site Rit), Archaeology and Science II, (2006), 21-26.

\section{Миловановић 2004/5}

Миловановић, Б., Извештај са систематских археолошких ископавања на локалитету терме - Виминацијум 2004. године (Report on systematic archaeological excavations at the site of Viminacium in 2004), Археолошки преглед н.с. (Archaeological Reports n.s.) 2/3 (2004/5), 51-54.

\section{Mrđić and Jovičić 2014}

Mrđić, N., and Jovičić, M., Nalaz mamuta na lokalitetu Nosak, u: Arheologija u Srbiji, projekti Arheološkog instituta u 2012. godini, (eds.) D. Antonović, S. Golubović, V. Bikić, 2014, 54-57.

\section{Nikolić et al. 2011}

Nikolić, E., Anđelković, J. and Rogić, D., Archaeological Park as a Product of Emotional Design: Design and Organisation of a Park Based on the Exploration of Visitors' Emotions, Archaeology and Science VI (2010) 2011, 259-268.

\section{Nikolić 2012}

Nikolić, E., Putevima razvoja jednog arheološkog parka: Građevina Domvs Scientiarvm Viminaciuvm, u: Arheologija u Srbiji, projekti Arheološkog instituta u 2012. godini, (eds.) D. Antonović, S. Golubović, V. Bikić, 2012, 66-68.

\section{Nikolić et al. 2013}

Nikolić, E., Rogić, D. and Anđelković Grašar J., Catastrophes as an Inevitable Result of Civilisation Flow: Relocation and Dislocation of Historical Physical Structures at the Archaeological Site of Viminacium, Serbia, in: Studies on Disasters, Catastrophes and the Ends of the World in Sources, Acta Archaeologica Pultuskiensia, Vol. IV, (eds.) J. Popielska-Grzybowska, J. Iwaszczuk, Pultusk 2013, 205-214. 


\section{Nikolić and Bogdanović 2012}

Nikolić, E and Bogdanović, I., Proučavanje maltera iz viminacijumskog amfiteatra kao osnova za njegovu buduću konzervaciju i restauraciju, u: Arheologija u Srbiji, projekti Arheološkog instituta u 2012. godini, (eds.) D. Antonović, S. Golubović, V. Bikić, 2012, 58-61.

\section{Nikolić et al. 2014}

Nikolić, S., Bogdanović, I. and Jevtović, Lj., Arheološka istraživanja viminacijumskog amfiteatra u 2012. godini, u: Arheologija u Srbiji, projekti Arheološkog instituta u 2012. godini, (eds.) D. Antonović, S. Golubović, V. Bikić, 2014, 58-62.

\section{Nikolić and Bogdanović 2012}

Nikolić, S., and Bogdanović, I., Istraživanja viminacijumskog amfiteatra u toku 2011. godine, u: Arheologija u Srbiji, projekti Arheološkog instituta $u$ 2012. godini, (eds.) D. Antonović, S. Golubović, V. Bikić, 2012, 42-45.

\section{Paardekooper 2012}

Paardekooper, R. P., The Value of an Archaeological Open-Air Museum is in its use. Understanding Archaeological Open-Air Museums and their Visitors, Leiden, Sidestone Press 2012.

\section{Redžić et al. 2006}

Redžić, S., Raičković, A. and Miletić, V., Arheološka istraživanja lokaliteta Stig na osnovu georadarskih ispitivanja (Archaeological Research at the Site of "Stig" Based on GPR Survey), Archaeology and Science I, (2006), 47-56.

\section{Pewnh 2008}

Реџић, С., Извештај о археолошким истраживањима локалитета Пиривој, Виминацијум, у 2005. години, (Report on the archaeological rescue excavations at the site of Pirivoj, Viminacium, season 2005) Археолошки преглед н.с. (Archaeological Reports n.s.) 2/3 (2004/5), 2008, 59-61.

\section{Rogić et al. 2007}

Rogić, D., Despotović, D. and Milovanović, B., Fragmenti zidnog slikarstva sa termi iz Viminacijuma (Fragments of wall paintings discovered in thermae at Viminacium) Archaeology and Science III (2007), 75-82.

\section{Rogić and Bogdanović 2012}

Rogić, D. and Bogdanović, I., Slikana dekoracija zida arene amfiteatra u Viminacijumu, u: Arheologija u Srbiji, projekti Arheološkog instituta u 2012. godini, (eds.) D. Antonović, S. Golubović, V. Bikić, 2012, 46-49.

\section{Спасић-Ђурић 2002}

Спасић-Ђурић, Д., Виминацијум главни град римске провиниије Горње Мезије, Viminacium the capital of the Roman province of Upper Moesia, Пожаревац 2002.

\section{Tapavički-Ilić 2013}

Tapavički-Ilić, M., Viminacium - Archäologischer Park Entwicklung und Perspektive, in: L. Č. Popović, M. Vidaković, Đ. S. Kostić (eds.), Resources of the Danubian Region: the Possibility of Cooperation and Utilisation, (2013), 315-326.

\section{Tapavički-Ilić and Anđelković Grašar 2013}

Tapavički-Ilić, M., and Anđelković Grašar, J., OpenArch, European project of popularising archaeology, Archaeology and Science 8 (2012), 2013, 97-100.

\section{Tapavički-Ilić and Mrđić in print}

Tapavički-Ilić, M., and Mrđić, N., Eksperimentalna arheologija Kremacija i priprema groba tipa Mala Kopašnica - Sase, in: Arheologija u Srbiji, projekti Arheološkog instituta u 2013. godini, (ed.) D. Antonović, in print.

\section{Валтровић 1884a}

Валтровић, М., Откопавања у Костолцу, Старинар 1 (1884), 3-14. 


\section{Валтровић 1884b}

Валтровић, М., Откопавања у Костолцу, Старинар 4 (1884), 121-142.

\section{Bacuh 1895}

Васић, М., Колонија Виминацијум-археолошка студија, Старинар XII (1895), 1-61.

\section{Васић 1907}

Васић, М., Неколике гробне конструкције из Виминацијума, Старинар н.р. II (1907), 67-98.

\section{Зотовић 1986}

Зотовић, Љ., Јужне некрополе Виминација и погребни обреди, Viminacium 1, (1986), 41-60.

\section{Зотовић and Јордовић 1990}

Зотовић, Љ. and Јордовић, Ч., Viminacivm: некропола “Више гробаља”, Београд 1990.

\section{Зотовић 2000}

Зотовић, Љ., Промене погребних ритуала током пет векова историје Виминација, Саопштења XXX/XXXI (1998/1999), 2000, 7-17.

\section{Internet sites and links:}

www.viminacium.org.rs www.ciutadellaiberica.com.

www.foteviken.se.

www.kierikki.fi.

www.archeon.nl.

www.hunebedcentrum.nl.

www.steinzeitpark-dithmarschen.de.

www.parcomontale.it.

www.museumwales. ac.uk/en/stfagans.

www.exeter.ac.uk/archaeology.

www.viminacium.org.rs.

www.exarc.net.

http://openarch.eu/work-packages/dialogue-visitors

\section{REZIME}

\section{VIMINACIJUM I OPENARCH PROJEKAT}

\section{KLJUČNE REČI: OPENARCH, VIMINACIJUM, ARHEOLOŠKI MUZEJI NA OTVORENOM, ARHEOLOŠKI PARK, EKSPERIMENTALNA ARHEOLOGIJA, POPULARIZACIJA.}

OpenArch je projekat Evropske Unije iz programa "Kultura", koji okuplja jedanaest partnera, među kojima je projekat Viminacijum Arheološkog instituta u Beogradu, jedini partner iz regiona jugo-istočne Evrope, tj. Balkana. Viminaciujum učestvuje na random paketu "Dijalog sa posetiocima”. Osnovni cilj ovog paketa je da se arheologija kao nauka približi posetiocima muzeja na otvorenom, kroz metode projekta OpenArch. Kroz učešće u različitim radionicama, sastancima i razmeni zaposlenih u okviru projekta OpenArch, Arheološki park Viminacijum dobija značajnu ulogu u širenju informacija i razmeni iskustava u naučnoj i stručnoj javnosti u Srbiji. U okviru radnog paketa posvećenog eksperimentalnoj arheologiji, dva eksperimenta su sprovedena na Viminacijumu, tako otvarajući novo polje istraživanja $\mathrm{u}$ viminacijumskom interdisciplinarnom timu. 